\title{
Strategic Management from the Perspective of SMEs Operating in Service Sector
}

\author{
DOI: 10.12776/QIP.V25I2.1549
}

Tibor Zsigmond, Renáta Machová, Annamária Zsigmondová

Received: 2021-02-25 Accepted: 2021-07-17 Published: 2021-07-31

\begin{abstract}
Purpose: Providing high quality services is a basis for long-term competitiveness of small and medium-sized enterprises. Recognizing the success factors of transformation and strategic management is an issue that has been frequently addressed in the past two decades. The goal of this article is to evaluate the strategy of small and medium-sized enterprises offering services in tourism and catering.
\end{abstract}

Methodology/Approach: The qualitative analysis was based on 107 completed interviews. Two hypotheses were formulated and an Independence Test was applied. Chi-square Test and Cross Table Analyiss were used which enable to examine the relationship between 2 non-metric variables. The two examined variables related to our Hypothesis 1 were ordinal, and 1 ordinal, 1 nominal in the case of Hypothesis 2 . The significance level was $\mathrm{p}=0.05$.

Findings: The obtained results show weak relationship between the size of the business and the awareness of the strategy. No relationship can be detected between the size of the business and the evaluation of the key success factor

Research Limitation/Implication: The research activity and obtaining research data from SMEs was obstacled by the pandemic situation caused by COVID-19. The research was limited by external circumstances, so the interviews with company representatives could be conducted on online platforms.

Originality/Value of paper: The paper examines how successful the SMEs involved in the research are in communicating the values and goals of the company to their employees. It brings important findings in the field of stretegy management which leads to high quality services in the case of providers.

Category: Research paper

Keywords: strategic management; mission; vision; competitiveness; strategy 


\section{INTRODUCTION}

Strategy, strategic thinking and strategic management are concepts that evoke respect and recognition. The concepts are associated with strong and charismatic personalities acknowledged in the field of small and medium-sized enterprises.

A company's prospects for the future are objectively and timely structured. Every enterprise needs to develop a strategy to help them keep up with the changes taking place in the market. There is no single strategy that would be the best solution for all companies. Each organization needs to find the path that seems most reasonable in the given circumstances, taking into account its own current situation, opportunities, goals, and tools. The idea of the farthest time horizon comes in the form of a vision, which has an inspiring effect and a challenge both inside and outside stakeholders. It is not very important in what order the parts of the future orientation are formulated, the point is that they are ultimately connected to each other logically and in chronological order, from the vision to the goals through the mission.

The strategic management principles and processes should change and adapt to the changing world economic environment. The strategic management of businesses should include several factors and considerations (Joyce and Woods, 1996). The information age, pandemics and globalization made the tactics more complicated, sophisticated and radical. It is important the businesses remain flexible and apply strategies that help the employees to change and modify the strategies that do not work (Genus, 1995; Chandler, 1992). New strategies and methods are introduced to implement paradigm shifts in the organizational environment. Careful analysis of the business environment, including the external, general, industrial, competitive and the internal organizational environment. Richardson and Richardson (1992) made the "total approach" strategic management equivalent with different forms of planning: a) planning aspriations; b) corporate and competitive planning; c) emergency planning; d) administrative planning; e) productivity planning; f) team culture planning;

g) innovation planning; h) shock event planning (AlQershi et al., 2020).

\section{THEORETICAL BACKGROUND}

\subsection{Strategic Management}

Strategy (strategic approach) is a wide range of opportunities to address certain challenges and objectives. Strategy is made up of decisions, reactions, activities that increase the chance for success and decrease the risk to fail to meet the goals. Each business strategy is therefore a unique masterpiece. These ideas were confirmed by Porter (2004), Souček (2005) and Magretta (2012) - sustainable competitive advantage can be achieved by applying strategy (Szemere, GaraiFodor and Csiszárik-Kocsir, 2021). 
The fundamental question of strategic management is how organizations achieve and maintain their competitiveness (Teece, Pisano and Shuen, 1997; Johnson and Scholes, 2000), and as a result of this how they outperform the industry average. Since both the business environment and the companies are constantly changing, it is a great challenge to achieve equilibrium and gain competitive advantage. The process of strategic management focuses on how companies achieve awareness, how the company can define the goals and objectives, as well as the implementation and evaluation of achievement of these goals. The strategy serves as a reference point for the members of the organization in terms of growth and development of the organization. A strategy is successful when results in competitive advantage of the company, the chosen strategies are viable and create a value both for the players and stakeholders. Thompson (1995), Ward and Peppard (2013), Aaker and Moorman (2017) pointed out that the success of strategy depends on the corporate or organizational culture and values, as well as the strength and style of the leader of the strategy. If the culture and values of the organization had adapted the change, the success would have come easier (Papula, 2004; Galabova, 2021).

Strategic thinking is a combination of convergent, divergent and creative thinking, combined with critical judgement (Ambrosini, Johnson and Scholes, 1998). The perspective of strategic brainstorming means that the new strategic ideas born as a consequence of the mental modell of strategy and business processes (Hamel et al., 1999). If the strategist can develop ideas and can see them from different perspectives, the ideas can be diverse and creative. It is important to recognize how to position the organization in order to maximize opportunities, while minimizing the threat of the environment. Implementing the selected strategies requires the synthesis of the alternative strategies, their possible impacts and outcomes. The Gap analysis helps the leaders to understand the dynamics of the competitive environment (Ambrosini, Johnson and Scholes, 1998; Anyakoha, 2019).

Winslow (1996) tbought that the "mission statements" count a bit more than the wishlists, unless they fall among the achievable goals the company determined. He encouraged the detailed business analysis before determining the strategic goals. Benchmarking, customer service research and business replanning were the three methods business leaders applied to expand their business analysis or decide their business goals and objectives. "Strategic management was rather to achieve a balance between the mission and activity of the organization and the wider environment of its resource capacities" (Genus, 1995, p.8). The linear approach to strategic management is outdated due to the constant and unpredictable changes on the global markets. The development and protection of organizational resilience preserves the resources of the organization and strengthens the abilities during change and chaos.

The crucial need for change within organizations cannot be implemented until the legacy of old, embedded cultures and management is disintegrated and transformed. The attitudes, values and beliefs have to be examined and 
redirected. "New organizational structures, new skills and knowledge, new employees, new information systems and leadership approach is required" (Bainbridge, 1996, p.11). Outdated processes have to disappear, and new processes based on updated technology and thinking, successful in the $21 \mathrm{st}$ century have to prevail. The businesses have to progress in transition. During the transition period, the organizations have to remain on the market, maintain their interest and competitiveness, achieve profit targets, and keep pace with techonological development. The traditional company values of the past: stability, adequacy and consistency can be an obstacle to fulfil the new mission and strategies of organizations (Aliperti and Cruz, 2020).

The strategic activities are necessary for the new and efficient strategic management of the new century in terms of the human resources aspect of the business, technological development and the infrastructure of the organization. In a changing global business environment, the effective goals and missions have to be specific, flexible, adaptable and insipiring, but measurable; they should be easy to understand, but not enough easy to be simplified; both for the customer and other stakeholders; they should be real in terms of chronology, yet include quality (Mura and Sleziak, 2014). "Needless to say, the appropriate balance of these paremtres is extremely difficult" (Hitt, Ricart and Nixon, 1998, p.36). The effectiveness of the mission can be measured by variable indicators: the extent to which the member of organizations are moving in clear direction; how inspiring it is, and generating the passion and commitment in the performance of the company.

In recent years, the most commonly applied methods in the field of corporate performance management are primarily Benchmarking, Strategic Planning, Vision and Mission Statement, CRM (Customer Relationship Management), Outsourcing and the Balanced Scorecard. In addition to these methods and concepts, further tools have been used in recent years such as Change Management Programmes, Strategic M\&A, Core Competencies, Strategic Alliances and Customer Segmentation. Most of these tools are an integral part of the coherent concept of strategic performance managmenet of the business. Accoring to Rajnoha and Lorincová (2015), companies operating in the selected sectors of the Slovak economy, while providing outstanding performance, have a strong focus on managing strategic performance by applying several modern methods and concepts. According Bobenič Hintošová et al. (2020) knowledge of the connections among individual factors, as well as quantification of their effects, both in relation to business performance and among them, can have a significant pragmatic impact, particularly in terms of the business strategy development and its implementation (Bobenič Hintošová, Bruothová and Vasková, 2020). Mura, Žulová and Madleňák (2016, p.83) state “In the future, additional legislative cooperation with social partners is expected to initiate further steps in strategic management that will lead to building a knowledgebased society and strengthening of the services sector as the future fields in which to create new, modern jobs". 


\subsection{Values, Mission, Vision and Quality}

Drafting vision and mission statements are a strategic decision made by the top management or the owners. Mission is a term used to describe our main activities. In business context it refers to customers (what kind of needs I would like to satisfy), the external envirionment and the market in which the company operates.

Vision is related to the quality objectives of the company, because it describes what the company wants to achieve. According to Mallya (2007, p.29) "vision can be percieived as a mental model of the future state or as a positive reflection of the future of the organization". Košt'an and Šuleř (2002, p.11) add that "vision is a unifying element, which is a challenge, inspiration, support or meaning of effort for the people working in the company". According to Kourdi (2011, p.128), "it is not enough to define vision as a future perspective unifying the employees of the company". It should also contain a set of values specific for the company and the employees, which would have a function of decision-making and negotiation. Mathur and Kenyon (1998, p.39) stated: “A company is often said to have an explicit or implicit system of values, which is part of its culture. What is meant, is that the management team has a collective set of values, so that the company is used as a shorthand expression for the collectivity of the managers. An example might be a dedication to the quality of what is offered to customers". According to Forbes Insights (2014) "It is an easy matter to state quality goals. But actually taking action to achieve those goals requires strong commitment: a compelling vision, companywide shared values and complementary performance metrics and incentives". They analyzed responses from more than 2,000 executives and quality professionals. Only half, 51\%, said that the quality vision is understood within the organization. Papula, Papulová and Papula (2019) presented that vision is a key idea determining goals, activities and strategy of the company. The vision forecasts how the company should look like in the future. Vision has to express the customer philosophy, internal policy, relationship and commitments to partners and the environment, awareness of company about its position on the market. According to them, the vision presents the future position of the company, pays attention on trends, factors and phenomena currently uncertain. Antošová (2012) claims that the most important while creating a vision is intuition, mental abilities, imagination, receptivity and ability to predict the future. The vision has to initiate people to act in order to succeed, therefore an effective vision inspires, motivates and provides emotional guidance. Its importance has to be highlighted also in the case of small and medium-sized enterprises (Bartkus, Glassman and McAfee, 2004; Bratianu and Balanescu, 2008; Al-Hanakta, Horuz and Corekcioglu, 2020).

According to Zgodavova and Bober (2012, p.59) “The ISO (International Organization for Standardization) standards positively contribute to the running of the world we live in". The newest verison of ISO standard (ISO 9001: 2015 Standard) contains strategic management concepts too. It gives us an opportunity to put business school concepts and theories into use. With the help of it, 
strategic management and quality management come together as determining the organizations context (Fonseca and Lima, 2015; ISO, 2016).

\subsection{Corporate Success Factors}

Companies are put under pressure by external environmental factors, while they are trying to maintain their competitiveness on the aggregate markets. They strive to formulate strategies that help them create more value for their customers. Strategic thinking provides a guidance for examining those segments of the market that seem to be relevant in terms of the company's operation. Theories and management models serve as a guide to increase the competitive advantage of the company. Strategic thinking helps the company to define the company goals and objectives, develop key policies and plans to achieve the defined goals, which identify and clarify the activities of the business and have positive impact on the performance. Factors important in terms of competitive advantage can be identified that will explain the relationship betwee the company's performance and the motivation behind the performance. The corporate success factors refer to activities and solutions that are crucial in "defeating" the competitors (Day and Wensley, 1988; Sousa and Hambrick, 1989). Several authors have addressed the discussed issue. Grunert and Ellegaard (1993, p.264) summarized it as the follows:

- The corporate success factors are relevant in all areas of the business, as they include the necessary resources and the abilities characteristic for the company;

- Market-driven, as their main goal is to ensure the competitive advantage of the company;

- Their number is limited, as only a few components show a significant connection to corporate success;

- A causal relationship exists between the specific skills of the company and the required resources and competitive advantage.

The corporate success factors target the companies with tasks that are necessary to achieve and maintain their position. The last of the listed characteristics includes the dynamic characteristic of success factors. According to D'Aveni (1994), the increased competition results in faster change of success factors. However, this is limiting their identification.

The concept of success factors is focusing on two research fields. It is primarily concerned with defining the resources and skills. Grunert and Ellegaard (1993) differentiate the mentioned concepts. According to them, the basic resources and skills are those the company needs to operate on the market. These tools are of unique importance to each company and also differ in terms of competitive advantage. Varadarajan (1985) argues that specific skills and resources are rather preventing failure than being a key to success. The most important success 
factors are those resources, which contribute to maintaining the competitive advantage. Furthermore, it assumes that competitive advantage and the company performance are correlated, because the competitors do not evaluate these skills and tools in a uniform manner.

According to Bharadwaj, Varadarajan and Fahy (1993), the second field is related to the study and analysis of identification of these success factors, so their examination can contribute to defining the general theory of competitive advantage. Based on these, 2 types of viewpoints can emerge. As one point of view, they logically testify the reasons for success, on the other hand they refer to company performance in terms of parallelism between these factors and market attractiveness. As a consequence, the success factors may lose their value due to negative market features.

The research is focusing on those success factors that were also defined by Magyar (2009a) in his study. This can be explained by a simple fact that the SMEs in the researched area are focusing on stabil customer base, modern technology, unique resources and the professional skills of the employees. The second hypothesis is also based on this assumption (Magyar, 2009b; AlQershi et al., 2020).

\section{METHODOLOGY}

The goal of this article is to assess the strategy of small and medium-sized enterprises providing tourism and catering services. The another purpuse is to draw attention to the importance of vision and mission. The theoretical part introduced the concept of strategic management, corporate vision and mission. A short description was provided about the corporate success factors. The research is based on interview survey. Structured interview as a part of the research was designed for the managers of SMEs. Demographic questions were also included that were necessary to identify the size of enterprises (micro, small, mediumsized). We used a database to reach (website containing data of companies) the potential enterprises. The current analysis is based on 107 completed interviews. We targeted only those enterprises that employ further employees beside the company owner. These employees could not be family members.

It is important to highlight that the interviews had to be stopped due to the pandemic situation caused by COVID-19. Most of the tourism and hospitality businesses had to slow down their activities. The interviews were conducted with the managers of the companies (employees were not involved) as they can provide the most relevant information about the situation of the business. We used a limited number of open questions. The interviews were conducted on different online platforms e.g. Skype, Meet, BBB, Microsoft Teams. During the first few interviews we asked the managers of companies to forward the interview questions to potential company managers working in hospitality and 
tourism industry. As a result of this, some of the company managers contacted us for the interview.

Two hypotheses were formulated during the research:

H1: There is a relationship between the size of the business and the strategy, vision awareness.

H2: $\quad$ There is a relationship between the size of the business and the evaluation of the key success factors.

The above mentioned hypotheses are examined in details below. We applied an independence test. A Cross-Tabulation Analysis and Chi-Square test were used as statistical methods, which allow us to examine the relationship between 2 non-metric variables. We examined 2 ordinal variables in the case of Hypothesis 1, while 1 ordinal and 1 nominal variable was examined in the case of Hypthesis 2. The significance level of $\mathrm{p}=0.05$ was determined.

\section{RESULTS AND DISCUSSION}

The introduction of obtained results will start with an introduction of demographic data. $34.3 \%$ of the respondents were female business leaders, while $65.4 \%$ were male respondents. Most of the respondents belonged to the age group 36-50. No responds were obtained from leaders under 20. The last question was interested in the highest achieved qualification of the respondent. Most of the respondents have completed vocational high school and passed final exam. The ratio of respondents with second level of university degree (Msc) was $17.8 \%$, the same ratio was achieved by the respondents with vocational high school degree without final exam. The obtained results are summarized in the table below.

After examining the characteristics of company leaders, we found it necessary to map the characteristics of companies as well. We were interested in types of the companies involved in the research. The companies we examined are mainly limited liability companies, part of them are run by registered entrepreneurs. Regarding the years of existence of the business, the researched companies show a colourful picture. Compared to medium-sized enterprises, the ratio of micro and small enterprises was higher in the sample. 
Table 1 -Summarized Data about the Leaders and the Enterprises

\begin{tabular}{|c|c|}
\hline \multicolumn{2}{|l|}{ Age group } \\
\hline Under 20 & $0.0 \%$ \\
\hline 20-35 & $19.6 \%$ \\
\hline $36-50$ & $54.2 \%$ \\
\hline $51-65$ & $19.6 \%$ \\
\hline $65+$ & $6.5 \%$ \\
\hline \multicolumn{2}{|l|}{ Gender } \\
\hline Female & $34.3 \%$ \\
\hline Male & $65.7 \%$ \\
\hline \multicolumn{2}{|l|}{ Age of business } \\
\hline $0-2$ years & $8.4 \%$ \\
\hline $2-5$ years & $21.5 \%$ \\
\hline $5-10$ years & $22.4 \%$ \\
\hline $10-15$ years & $27.1 \%$ \\
\hline More than 15 years & $20.6 \%$ \\
\hline \multicolumn{2}{|l|}{ Education } \\
\hline Vocational high school (Without gradution) & $17.8 \%$ \\
\hline Vocational high school (Gradution) & $47.7 \%$ \\
\hline Grammar school & $10.3 \%$ \\
\hline University (Bsc. diploma) & $5.6 \%$ \\
\hline University (Msc. diploma) & $17.8 \%$ \\
\hline University (PhD. diploma) & $0.9 \%$ \\
\hline \multicolumn{2}{|l|}{ Type of business entity } \\
\hline Limited liability company & $49.5 \%$ \\
\hline Self entrepreneur & $50.5 \%$ \\
\hline \multicolumn{2}{|l|}{ Size of the business } \\
\hline Micro-enterprise & $45.8 \%$ \\
\hline Small business & $41.1 \%$ \\
\hline Medium-sized business & $13.1 \%$ \\
\hline
\end{tabular}

The first hypothesis was the following: "There is a relationship between the size of the business and the strategy, vision awareness". In order to test the hypothesis, we had to select the collected data. We wanted to examine the relationship between the business size (independent, ordinal), strategy and awareness of business vision (dependent, ordinal). We had to conduct an independence test. We obtained the following values. 


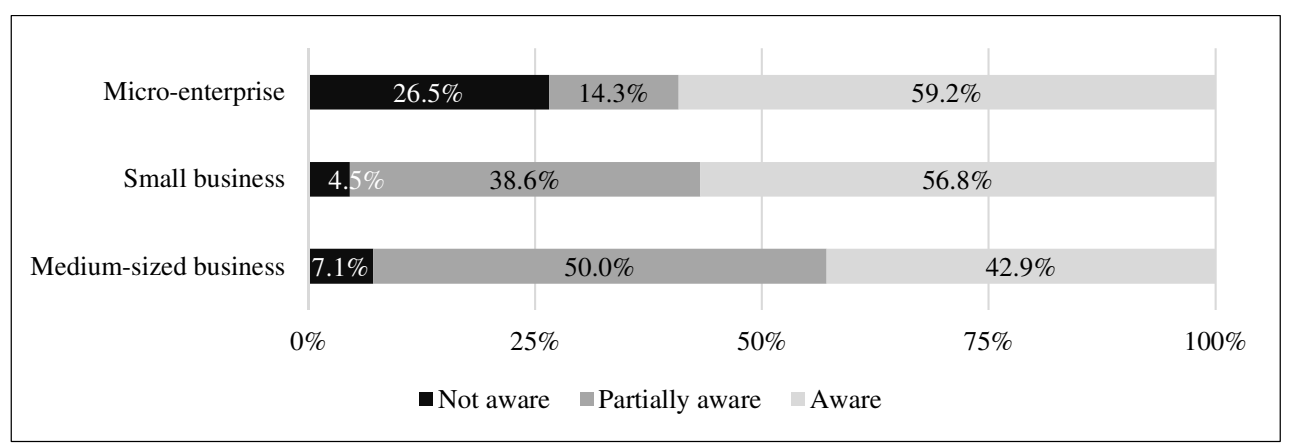

Figure 1 - Business Size and the Awareness of the Strategy

Since both of the variables are ordinal - not metric variables - we applied a crosstab. The statement sounds that there is no relationship between the observed variables. Pearson's Chi-square $(\chi 2)$ test was used to perform the test. We obtained the following values by applying SPSS.

Table 2 - The Result of the Pearson Chi-Square test - Hypothesis 1

\begin{tabular}{|l|c|c|c|}
\hline & Value & Df & Asymp. Sig. (2-sided) \\
\hline Pearson Chi-Square & 15.879 & 4 & 0.03 \\
\hline Likelihood Ratio & 16.757 & 4 & 0.02 \\
\hline Linear-by-Linear & 0.409 & 1 & 0.523 \\
\hline N of Valid Cases & 107 & & \\
\hline
\end{tabular}

The value of the Chi-square is 15.879 ; the value of the degree of freedom (df) is 4 ; the significance $(\alpha)$ value is 0,05 . The critical value of the $\chi^{2}$ (in case that the degree of freedeom $(\mathrm{df})=2$, the level of significance is 0.05 ) based on the table of quantile values of the Chi square distribution is 9.488. According to this, $15.879>9.488$ means that $\chi^{2}>\chi 2$ crit. The value of $\mathrm{P}$ (empirical significance level) is 0.003 , which is higher than the significance level $(\alpha=0.05)$. Based on these results, there is relationship between the size of the business and the awareness of the strategy, mission. Since there is relationship, it is necessary to examine the relationship between the two ordinal variables (Gamma coefficient). The results were obtained by using SPSS program. The value is 0.019 , which shows a weak, positive relationship between the variables. According to these results, the employees of bigger companies aware of company vision more than those of smaller enterprises. The "partially aware" option was also considered. 
Table 3 - The Value of Gamma Coefficient - Hypothesis 1

\begin{tabular}{|l|c|c|c|c|}
\hline & Value & Asymp. Std. Error & Approx. T & Approx. Sig. \\
\hline Ordinal by Ordinal - Gamma & 0.019 & 0.151 & 0.124 & 0.901 \\
\hline N of Valid Cases & 107 & & & \\
\hline
\end{tabular}

According to the $\mathrm{H} 2$ hypothesis: "There is a relationship between the size of the business and the assessment of the key success factors". We wanted to examine the relationship between differentiation based on the size of the business (independent, ordinal) and the evaluation of the key success factors (dependent/nominal). We performed an independence analysis. First, we got the following value.

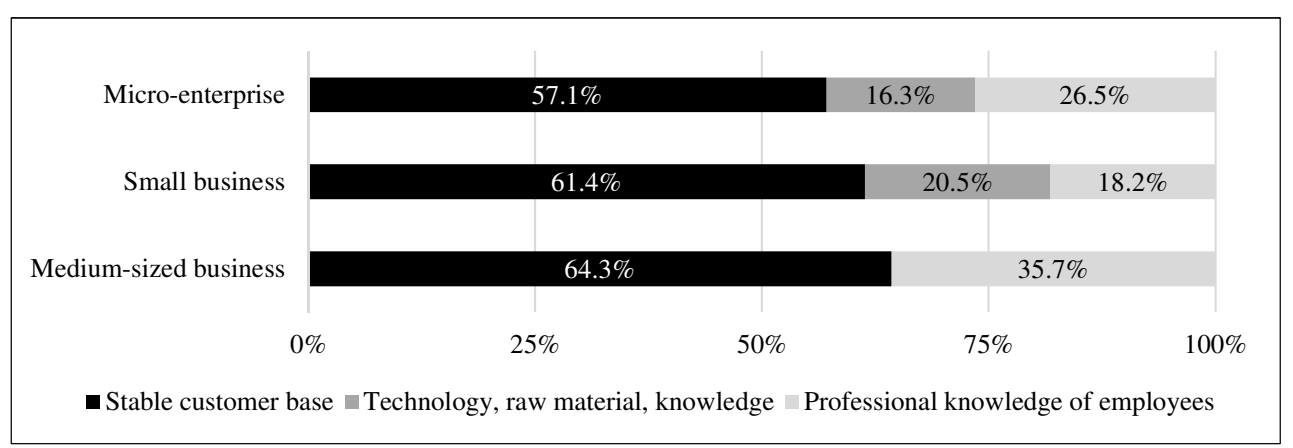

Figure 2 - Evaluation of the Key Success Factors for each Company Type

One of the variables is ordinal and the second is nominal, so a crosstab was used in this case as well. The basic statement was that there is no relationship between the two examnied variables (income, expenditure). The rule of the feasibility test was met, so we applied the Pearson's Chi-square ( $\chi 2)$ test. Using SPSS, we obtained the following values.

Table 4 - The Result of the Pearson Chi-Square Test-Hypothesis 2

\begin{tabular}{|l|c|c|c|}
\hline & Value & Df & Asymp. Sig. (2-sided) \\
\hline Pearson Chi-Square & 4.459 & 4 & 0.347 \\
\hline Likelihood Ratio & 6.601 & 4 & 0.159 \\
\hline Linear-by-Linear & 0.055 & 1 & 0.815 \\
\hline N of Valid Cases & 107 & & \\
\hline
\end{tabular}

The value of the Chi-Square is 4.459. The value of the degree of freedom (df) is 4 . The significance value $(\alpha)$ is 0.05 . The critical value of $\chi 2$ distribution (degree of freedom $(\mathrm{df})=4$, the significance level $=0.05$ ) based on the table of the quantile values of Chi-Square distribution is 12.592. According to this: $4.459<9.488$ 
means that $\chi^{2}<\chi 2$ crit. Furhtermore, the value of $\mathrm{P}$ (empirical significance level) is 0.347 , which is higher than the level of significance $(\alpha=0.05)$. The obtained results prove that there is no relationship between the size of the business and the evaluation of the key success factors.

\section{CONCLUSION}

The aim of the research was to examine the strategy of small and medium-sized enterprises providing tourism and hospitality services and to raise the awareness about the researched field. In order to achieve the goal, a structured interview was applied. 107 interviews were made with the managers of those companies, which have at least one employee, who is not a family member.

Two hypotheses were formulated, the first of which was related to strategy and vision of the company. Van der Walt, Kroon and Fourie (2004) emphasized the importance of strategic management in the SME sector. Szabó (2016) argued that employees are more committed if they are familiar with the vision and long-term goals of the company. It is important that the employees understand and accept them and aware how their efforts contribute to success in achieving the goals. Improvement in employee commitment can be detected if they identify themselves with the goals and values of the company. Even though, strategy and vision awareness is not perceived as the most important factor for SMEs in Slovakia. Therefore, the aim of the research was to raise the awareness about the potentials of this field. Based on the research above, we examined how successful the SMEs involved in the research are in communicating the values and goals of the company to their employees. The hypothesis was confirmed, as the employees of small and medium-sized companies are generally aware of company strategy. It was confimed only in those cases if we consider also those companies where employees are only partially familiar with the strategy and vision of the company. Focusing on companies, where the managers reported that the employees are fully aware of the vision and strategy of the company, the ratio is higher for small enterprises. If we examine the companies where employees are less involved, the worst ratio is shown in the case of small enterprises.

The second hypothesis examined the importance of success factors. According to Magyar (2009a; 2009b), a stable customer base, modern technology, unique resources and the professional knowledge of the employees are the key success factors for SMEs. We were interested what is the most important factor for the researched companies operating in tourism and hospitality sector. Based on the obtained results, there is no relationship between the size of business and the evaluation of the key success factors, as a stable customer base was considered the most important.

The research activity and obtaining research data from SMEs was obstacled by the pandemic situation caused by COVID-19. The study was limited by external circumstances, so the interviews with company representatives could be 
conducted on online platforms. The plan is to extend the research to further countries of Central Europe. Most of the companies operating in hospitality and tourism sector spend not adequate time with online presence. The entrepreneurs spend most of their time with activities that are not closely connected with online presence.

It seems to be a good decision to conduct the research with participation of the same enterprises in the future. It would be possible to observe which companies survived the pandemic, and what is the ratio of those companies had to quit their operation or went bankrupt. The interview has to be updated with further questions. The plan is to involve also large companies in order to make a broader comparison on the market. A questionnaire survey can be applied and distributed among the employees of the company as a tool to get information from different perspective as well.

\section{ACKNOWLEDGEMENTS}

The research team would like to express its gratitude to our institution, J. Selye University, supporting the research activity of the team.

\section{REFERENCES}

Aaker, D.A. and Moorman, C., 2017. Strategic Market Management. New Jersey: Wiley.

Al-Hanakta, R., Horuz, D. and Corekcioglu, S., 2020. Sustainable Innovation Development in Jordanian SMEs And Startups. In: D.K. Dimitrov, D. Nikoloski and R. Yilmaz, eds., Proceedings of XIV. International Balkan and Near Eastern Social Sciences Congress Series on Economics, Business and Management. Plovdiv, Bulgaria, 26-27 Sept. 2020. Bulgaria: University of Agri. and Rural Development, University “St. Kliment Ohridski”, IBANESS. pp. 404-412.

Aliperti, G. and Cruz, A., 2020. Promoting built-for-disaster-purpose mobile applications: An interdisciplinary literature review to increase their penetration rate among tourists. Journal of Hospitality and Tourism Management, [e-journal] 44, pp.193-210. DOI: 10.1016/j.jhtm.2020.06.006.

AlQershi, N.A., Diah, M.L.B.M., Latiffi, A.B.A. and Ahmad, W.N.K.W., 2020. Strategic Innovation and Competitive Advantage of Manufacturing SMEs: The Mediating Role of Human Capital. Quality Innovation Prosperity, [e-journal] 24(3), pp.70-89. DOI: 10.12776/qip.v24i3.1493.

Ambrosini, V., Johnson, G. and Scholes, K., 1998. Exploring techniques of analysis and evaluation in strategic management. New York: Prentice Hall.

Antošová, M., 2012. Strategický manažment a rozhodovanie. Bratislava: Iura Edition. 
Anyakoha, C., 2019. Strategic management practice and micro - small enterprises financial performance in Imo, South East Nigeria. Acta Oeconomica Universitatis Selye, 8(1), pp.41-52.

Bainbridge, C., 1996. Designing for change: A practical guide for business transformation. New York: John Wiley.

Bartkus, B.R., Glassman, M. and McAfee, R.B., 2004. A comparism of the quality of European, Japanese and US mission statements: a content analysis. European Management Journal, [e-journal] 22(4), pp.393-401. DOI: 10.1016/j.emj.2004.06.013.

Bharadwaj, S.G., Varadarajan, P.R. and Fahy, J., 1993. Sustainable competitive advantage in service industries: a conceptual model and research propositions. Journal of Marketing, [e-journal] 57(4), pp.83-99. DOI: 10.1177/002224299305700407.

Bobenič Hintošová, A., Bruothová, M. and Vasková, I., 2020. Does Foreign Direct Investment Boost Innovation? The Case of the Visegrad and Baltic Countries. Quality Innovation Prosperity, [e-journal] 24(3), pp.106-121. DOI: 10.12776/QIP.V24I3.1519.

Bobenič Hintošová, A., Hajduová, Z., Szajt M. and Bobenič T., 2020. The Influence of Firm-Specific Factors on Firm's Performance. Polish Journal of Management Studies, [e-journal] 21(2), pp.115-128. DOI: 10.17512/pjms.2020.21.2.09.

Bratianu, C. and Balanescu, G.V., 2008. Vision, mission and corporate values. A comparative analysis of the top 50 U.S. companies. Management \& Marketing, 3(3), pp.19-38.

Chandler, A., 1992. Strategy amd Structure. Cahters in the History of the American Enterprise. Cambridge, MA: MIT Press.

D’Aveni, R.A., 1994. Hypercompetition. New York: Free Press.

Day, G.S. and Wensley, R., 1988. Assessing advantage: a framework for diagnosing competitive superiority. Journal of Marketing, [e-journal] 52(2), pp.1-20. DOI: 10.1177/002224298805200201.

Fonseca, L.M., and Lima, V.M., 2015. Impact of Supplier Management Strategies on the Organizational Performance of ISO 9001 Certified Organizations. Quality Innovation Prosperity, [e-journal] 19(2), pp.32-54. DOI: 10.12776/qip.v19i2.592.

Forbes Insights, 2014. Culture of Quality: Accelerating Growth and Performance in the Enterprise. New York: Forbes.

Galabova, B., 2021. Open innovation - potential, constraints and prospects. International Scientific Journal Innovations, 9(1), pp.7-11.

Genus, A., 1995. Flexible strategic management. London: Chapman \& Hall. 
Grunert, K.G. and Ellegaard, C., 1993. The concept of key success factors: theory and method. Perspectives on Marketing Management, 3, pp.245-274.

Hamel, G., Prahalad, C.K., Howard, T. and O'Neal, D.E., 1999. Strategic Flexibility: Managing in a Turbulent Economy. Chichester: Wiley.

Hitt, M.A., Ricart, J.E. and Nixon, R.D., 1998. New managerial mindsets: Organizational transformation and strategy implementation. New York: J. Wiley.

ISO, 2016. ISO 9001:2015 for Small Enterprises - What to do? Geneva: International Organization for Standardization.

Johnson, G. and Scholes, K., 2000. Cesty k úspěšnému podniku. Praha: Computer Press.

Joyce, P. and Woods, A., 1996. Essential strategic management: From modernism to pragmatism. Boston, MA: Butterworth-Heinemann.

Košt'an, P. and Šuleř, O., 2002. Firemní strategie - plánování a realizace. Praha: Computer Press.

Kourdi, J., 2011. Podniková strategie. Průvodce rozvojem vašeho byznysu. Brno: Edika.

Magretta, J., 2012. Michael Porter jasně a zrozumitelně, O konkurenci a strategii. Praha: Management Press.

Magyar, Z., 2009a. Kisvállalatok stratégiai prioritásainak vizsgálata az észak alföldi régióban. Gödöllö: Szent István Egyetem.

Magyar, Z., 2009b. A study of product strategy priorities at the small enterprises of the North-Alföld Region. Acta Agraria Debreceniensis, [e-journal] 33, pp. 5564. DOI: $10.34101 /$ actaagrar/33/2852.

Mallya, T., 2007. Základy strategického řízení a rozhodování. Praha: Grada Publishing.

Mathur, S.S. and Kenyon, A., 1998. Creating Value: Shaping Tomorrow's Business. Oxford: Butterworth-Heinemann.

Mura, L. and Sleziak, J., 2014. Innovation and Entrepreneurship Network. Proceedings of the CERS 2014: 5th Central European Conference in Regional Science, International Conference Proceedings. Košice, Slovakia, 5-8 Oct. 2015. Košice: Technical University of Košice. pp.643-651.

Mura, L., Žul'ová, J. and Madleňák, A., 2016. Strategic management and management of personnel costs: employing young people in the Slovak Republic. Problems and Perspectives in Management, 14(1), pp.79-84. DOI: 10.21511/ppm.14(1).2016.09.

Papula, J., 2004. Vývoj teórie strategického manažmentu pod vplyvom zmien v prostredí. Bratislava: Karprint. 
Papula, J., Papulová, Z. and Papula, J., 2019. Stratégia a strategický manažment. Bratislava: Wolters Kluwer.

Porter, M.E., 2004. Competitive Strategy: Techniques for Analyzing Industries and Competitors. New York: The Free Press.

Rajnoha, R. and Lorincová, S., 2015. Strategic Management of Business Performance Based on Innovations and Information Support in Specific Conditions of Slovakia. Journal of Competitiveness, [e-journal] 7(1), pp.3-21. DOI: 10.7441/joc.2015.01.01.

Richardson, B. and Richardson, R., 1992. Business planning: An approach to strategic management. London: Pitman.

Souček, Z., 2005. Firma 21. storočia. Praha: Professional Publishing.

Sousa, J.A. and Hambrick, D.C., 1989. Key success factors: test of a general theory in the mature industrial - product sector. Strategic Management Journal, 10(4), pp.367-382.

Szabó, A., 2016. A munkavállalói elkötelezettség növelésének hatása és lehetőségei. Opus et Educatio, 3(4), pp.439-450.

Szemere, T. P., Garai-Fodor, M. and Csiszárik-Kocsir, Á., 2021. Risk ApproachRisk Hierarchy or Construction Investment Risks in the Light of Interim Empiric Primary Research Conclusions. Risks, [e-journal] 9(5), pp.84-100.

Teece, D.J., Pisano, G. and Shuen, A., 1997. Dynamic Capabilities and Strategic Management. Strategic Management Journal, [e-journal] 18(7), pp.509-533. DOI: 10.1142/9789812834478_0002.

Thompson, J., 1995. The CIMA handbook of strategic management. Oxford: Butterworth-Heinemann.

Van der Walt, L.J., Kroon, J. and Fourie, B.J., 2004. The importance of a vision and mission for small, medium-sized and large businesses. South African Journal of Economic and Management Sciences (SAJEMS), 7(2), pp.206-220.

Varadarajan, P.R., 1985. A two-factor classification of competitive strategy variables. Strategic Management Journal, 6(4), pp.357-75.

Ward, J. and Peppard, J., 2013. Strategic planning for information systems. London: John Wiley \& Sons.

Winslow, W., 1996. Strategic business transformation: Achieving strategic objectives through business re-engineering. New York: McGraw-Hill.

Zgodavova, K. and Bober, P., 2012. An Innovative Approach to the Integrated Management System Development: SIMPRO-IMS Web Based Environment. Quality Innovation Prosperity, [e-journal] 16(2), pp.59-70. DOI: 10.12776/qip.v16i2.69. 


\section{ABOUT AUTHORS}

Tibor Zsigmond ${ }^{0000-0002-2581-5519}$ (T.Zs.) - Department of Management, Faculty of Economics and Informatics, J. Selye University, Komárno, Slovakia, Msc., Assist. Prof., e-mail: zsigmondt@ujs.sk.

Renáta Machová ${ }^{0000-0002-7817-0187}$ (R.M.) - J. Selye University, Komárno, Slovakia, Assoc. Prof., Vice-Rector for Education and External Relations, e-mail: machovar@ujs.sk.

Annamária Zsigmondová0000-0002-9128-391X (A.Zs.) - Department of Economics, Faculty of Economics and Informatics, J. Selye University, Komárno, Slovakia, Msc., PhD. Student, e-mail: zsigmondova.annamaria@ student.ujs.sk.

\section{AUTHOR CONTRIBUTIONS}

Conceptualization, T.Zs. and R.M.; Methodology, T.Zs. and A.Zs.; Software, T.Zs. and A.Zs.; Validation, T.Zs.; Formal analysis, A.Zs.; Investigation, R.M.; Resources, T.Zs, R.M. and A.Zs.; Data curation, T.Zs.; Original draft preparation, R.M.; Review and editing, T.Zs, R.M. and A.Zs.; Visualization, T.Zs.; Supervision, A.Zs.; Project administration, R.M.; Funding acquisition, R.M.

\section{CONFLICTS OF INTEREST}

The authors declare no conflict of interest. The funders had no role in the design of the study; in the collection, analyses, or interpretation of data; in the writing of the manuscript, or in the decision to publish the results.

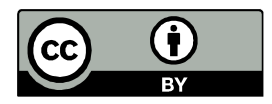

(C) 2021 by the authors. Submitted for possible open access publication under the terms and conditions of the Creative Commons Attribution (CC-BY) license (http://creativecommons.org/licenses/by/4.0/). 